\title{
Exploring film marketing in the new age digital era. Four cases of marketing European art house film productions
}

\section{Eirini Sifaki*}

School of Humanities and Social Sciences,

Department of Language and Intercultural Studies,

University of Thessaly,

Volos, 38221, Greece

Email: eirini_sifaki@yahoo.gr

*Corresponding author

\section{Maria Papadopoulou}

\author{
Hellenic Open University, \\ Parodos Aristotelous 18, TK 26 335, \\ Patra, Greece \\ Email: mary_papas7@yahoo.gr
}

\begin{abstract}
New age media platforms have for long been embraced in film marketing activities as new means to reach an audience, build product awareness and create audience anticipation. However, current research on transmedia film marketing concerns mainly Hollywood film products destined to a wide audience and orchestrated by colossal marketing firms. In this article, all four new age media marketing activities represent low budget European films that attempt to exploit the new opportunities offered in the new digital environment. Our analysis reveals how in the case of independent film marketing the use of transmedia activities builds new narratives that adds to the story and communicate the key values of the film. However, in order to establish a deeper interactive relationship between film directors, producers and their niche audiences, a clear understanding of the targeted audience's online behavioural pattern should be considered in the marketing actions design and implementation.
\end{abstract}

Keywords: film marketing; social media platforms; new age media marketing; traditional marketing mediums; poster; interaction; word-of-mouth; art house films.

Reference to this paper should be made as follows: Sifaki, E. and Papadopoulou, M. (2022) 'Exploring film marketing in the new age digital era. Four cases of marketing European art house film productions', Int. J. Cultural Management, Vol. 1, No. 1, pp.3-25.

Biographical notes: Eirini Sifaki an Associate Professor at School of Humanities and Social Sciences, Department of Language and Intercultural Studies, University of Thessaly and a Postdoctoral Researcher at the University of Crete. She holds a PhD in Information and Communication Sciences from the University Paris 3 - Sorbonne Nouvelle. Since 2004, she has been working for different universities (Aristotle University, University of Crete, Hellenic Open University) and collaborated in national and international research 
projects on cultural management and research ethics. She is the co-Editor of two books: City and Cinema: Theoretical and Methodological Approaches, Athens, Nissos (Greece) and World Film Locations, Athens, London, Intellect. Her own research has been published inter alia at Mésogeios (Méditerranée), Questions de Communication, Journal for Cultural Research, Visual Communication, etc. Her research interests and her publications involve issues on cultural sociology, media analysis and cultural communication.

Maria Papadopoulou is a Professor in En Dynamei Private School in Athens. Her research interests focus on arts management and marketing and has published a book entitled: Businesses' Organization and Management in 2010 (in Greek). Her recent publications include an article in collaboration with Eirini Sifaki with the title: 'Advertising modern art: a semiotic analysis of posters used to communicate about the Turner Prize award' for the journal Visual Communication in 2015. She has also undertaken a research for the European Parliament in collaboration with Eirini Sifaki and Anastasia Stamou about the emergence of a 'Greek Weird Wave', a new movement in Contemporary Greek Cinema in 2016.

\section{Introduction}

'Film marketing' is not an easy task, as the audience need to be convinced to choose among a wealth of other activities to spend their limited and valuable time to watch a film. It's like "selling a political candidate"; there is a unique window of opportunity open, in order to sell the film to as many film goers as possible [Cone, (2008), pp.109-110]. Being a holistic process, it encompasses many different stages, as the marketing process starts even before the film's production, when the idea of it was conceived in the mind of its creator [Mingant et al., (2015), p.2] and continues throughout its life cycle (production, distribution and exhibition) [Kerrigan, (2010), pp.9-10]. However, it does not end with the film product reaching its target audience in the movie theatres; it is extended in the film's official websites, social media platforms, in the audience's discussions with their friends or even when the audience is searching for another film by the same director or producer (p.10).

The emergence of new media platforms and communication channels has made a tremendous impact on the way films are marketed. First and foremost, it has totally transformed the way 'film marketing' strategies are built, from just focusing on the repetition of the (film's) brand to creating a narrative across different media channels [Meehan cited in Proffitt et al., (2007), p.241] (see also pp.7-8). New age media channels (social media platforms, websites, forums and video hosting services) offer, apart from easy access, prospect for interaction and rapid expansion of information (Akdeniz, 2015) and the potential for a more relevant and personal advertising message destined to a specific target group (Berte et al., 2008). Especially in the case of art house films - like the ones presented in this article - new media and technologies led to a rapid increase in the production of independent films and the emergence of independent filmmakers, mainly due to the opportunities created by new technological developments, such as, high-quality and inexpensive filmmaking equipment, online distribution channels etc. (Barnwell, 2019). 
While the majority of the literature focuses on new age media marketing schemes for big blockbuster Hollywood films (Nucci, 2018; Hardy, 2010; Kitsopanidou, 2014; Proffitt et al., 2007; Jenkins, 2006), such as, the 'Matrix', 'Avatar' or the 'Harry Potter' films, with major funds to spare on cross media promotion aiming at multi-platform brand expansions, this article seeks to explore how low budget independent films can equally exploit the possibilities offered by new age media platforms and services in promoting themselves in the new digital era. To this purpose, four online marketing strategies have been chosen from independent art house film productions. Our criteria for their characterisation as 'art house' films are based [Zaichkowsky et al., (2009), pp.213-4] on their limited financial resources, their European origin and spoken Greek language (apart from the 'The Lobster'). Furthermore those films have been classified by film critics and the films festival circuit as belonging to a new current in contemporary Greek cinema called 'The Greek Weird Wave' while their avant garde narrative and visual aesthetics, has won dithyrambic reviews by both critics and the press and gained extended recognition in film festivals [Sifaki et al., (2016), pp.176-182]. Given this media exposure which created a buzz in film festivals, transmedia practices have been incorporated into the marketing campaign adding to their avant garde aesthetics.

The main goal of this article is to showcase through the four films chosen to be presented how social media platforms and services can be incorporated in the promotion of the film, ranging from just reacting to a post or taking part in a contest to spreading 'positive word-of-mouth' and influencing online communities. In line with the case study approach [Eisenhardt, (1989), p.542] our aim is to understand the emergent relationships within the specific setting of independent art-house and digital marketing acts. Indeed, previous work on digital marketing and social media highlights the need for future research to focus more on the semantic analysis of social media and user generated content [Kannan and Li, (2017), p.28]. Our data source rely on qualitative elements and information of social interaction from an Instagram contest, Facebook and Twitter material and posts for these films, quiz games, etc. While our analysis focusses on the design and characteristics of these marketing acts, we seek to uncover how the digital environment reacted in relation to the outcomes of the specific marketing actions.

Even though the data collected do not reveal a great audience participation and interaction - these films dared to break through the clutter of traditional advertising strategies through ingenious online marketing interactive practices and explore the potentials offered by new age media platforms and services in an effort to overcome the obstacle aroused by the lack of funds. They also illustrate a form of immersive engagement which accounts for an emotional and intellectual deepening of the connection with the product. Therefore, apart from the standard media practices followed by all the films - such as the creation of an official film Facebook page or an official film website - the films 'Chevalier' (Tsangari, 2015), 'The Lobster' (Lanthimos, 2015), 'The Eternal Return of Antonis Paraskevas' (Psykou, 2013) and 'Attenberg' (Tsangari, 2010) attempted to build audience engagement via internet-based photo-sharing applications ('Instagram'), social networking services ('Facebook' and 'Twitter') and video-sharing websites ('YouTube'). Understanding the digital environment in terms of audience engagement and relating to the outcomes of marketing actions could have an impact for future design and implementation of film marketing strategies. 


\section{Transmedia practices in film marketing}

New age social media platforms and services have born new ways of media marketing, known as 'transmedia' and 'viral marketing'. What differentiates them from other traditional marketing tools is the emphasis placed on the audience's active role in the films' marketing process, in a more or less conscious way, and the opportunity offered for socialisation, interaction and 'word-of-mouth' stimulation. Through the use of social media networking, a more interactive relationship between the producer of a film and the audience-user can be established, as the latter can now actively participate in the film's funding, production (affecting in this way the final product) and promotion [Kerrigan, (2010), p.193].

'Transmedia marketing' aims to create an interactive narrative across different social media platforms alongside with the stimulation of audience participation, with a view to adding value to the overall 'film marketing' strategy. The first step is to create a story and then to 'scatter' its 'pieces' (information about characters, backstories, the plot) in different social media platforms, inviting the target audience to reconstruct it and usually be rewarded for doing so [Du Plessis, 2018; Bourdaa, (2014), p.19]. This new kind of marketing differs from a traditional marketing strategy as it takes it one step further, from just developing one story to developing a 'multimodal narrative world' in a variety of media and languages [Scolari, (2009), p.589]. Each medium engaged into a 'transmedia marketing' strategy can act both independently and in interplay with other media contributing to the narrative as a whole [Kafoury, (2013), p.5]. That means that the target audience can enjoy each marketing entry independently, whether they have prior experience with the film or not (Jenkins, 2003).

The benefits from a 'transmedia' marketing strategy can be enormous, not only for the audience, but also for the producer. From one standpoint, the audience is able to engage into the storytelling's creation and evolution and hence, acquire a better and fuller understanding of it (Zeiser, 2015). From another standpoint, the producer can access via a variety of social media platforms different audience segments [Yang and Zisiadis, (2014), p.4] by taking advantage the interactive features that each platform has to offer. Furthermore, 'transmedia marketing' is conducive to a film's branding strategy. Transmedia branding storytelling aims first at creating "a symbolic universe endowed with meaning", that is, a fictional universe that conveys the values of the film advertised and then, make the audience embrace those values and be enamoured with the film [Scolari, 2008, as quoted in Scolari, (2009), p.599]. Therefore, even before a film is launched in the screens its qualities and unique characteristics that according to its marketers make it stand out from the rest, are presented to the audience with a view to creating a degree of familiarity with the film and its values before it even comes out in the big screen [Bourdaa, (2014), p.19]. In this way, the audience becomes familiar with basic elements of the film, such as the characters or the plot, even before the film is launched in the big screen and a certain degree of anticipation is created ('augmented storytelling'). In fact, Frank Rose went even further by taking the emphasis from the process of 'transmedia' that is developing a narrative across different media platforms and placed it on its goal, the immersion of the audience into the storytelling which he defines as 'deep media' (cited in Bourdaa, 2012).

New social media platforms have, also, fostered an alternative way of 'film marketing', known as viral marketing. This new kind of marketing strategy acts on the base of exponential expansion via the interpersonal communication fostered by the new 
social media platforms (Akdeniz, 2015). Information expands and becomes available to multiple audiences in a matter of a few minutes in an inexpensive and effortless way by appointing to the readers the role of the marketer. In order for a 'viral marketing' strategy to be successful, according to Wilson (2012) it needs six fundamental elements giveaways, effortless transfer of information, going from small to large, motives, networks, exploitation of other resources - based on which the viral effect of the four social media practices that are going to follow will be evaluated.

As presented so far, new age media marketing strategies place the emphasis on the prospect of interaction offered to the audience via online platforms, websites and services, which can be viewed as an extension of 'word-of-mouth' communication [Mangold and Faulds, (2009), p.359] orchestrated by the producers in order to promote their films [Mingant et al., (2015), p.2]. Even though 'word-of-mouth' is highly unlikely to be controlled by marketers [Kerrigan, (2004), p.37], let alone to be measured in numbers, its influential power on the social media user can be, however, evaluated through the comments on the film's official Facebook page and 'likes', the official website's visitation hits or even the 'views' and 'shares' of the online YouTube videosharing website. Nonetheless, it cannot be deduced that the augmentation of the volume of 'positive word-of-mouth' or the visitation hits in social media platforms can certainly mean an increase in ticket sales, even though they can be connected with increased flow of information and interest stimulation about the film (Godes and Dina, 2004).

Especially in the framework of the films marketing schemes examined in this article, 'positive word-of-mouth' is an important factor of influence, as niche audiences tend to be highly affected by it for two reasons. The first one to be addressed is liability. Art audiences are influenced by positive word-of-mouth from their social media inner communication circle, as they consider it to be a liable source of recommendation [Liu, (2006), p.74; Allsop et al., (2007), p.398]. The other reason is 'accessibility', which is an important key feature of social media platforms, making them an essential and inexpensive viral marketing tool. The audience has now the chance not only to seek and find information regarding a film, such as the actors' biographies, film reviews, audience's commentaries, but also to act upon it by expressing their opinion on social media platforms creating positive or negative 'word-of-mouth', through their mobile phones, tablets or personal computers before, after or even while they are watching the film in the movie theatre (Galanou, 2012). What is more, it should be taken into consideration that art house audiences- - unlike commercial ones - have a more intellectual attitude towards films and a different social behaviour towards art [Austin in Zaichkowsky, (2009), p.213). They consider their experience with art house films not an entertaining one, but one that suits their artistic and cultural values [Touw, (2011), p.22] Therefore, a social media marketing strategy designed for an art house audience that aspires to achieve the maximum of 'positive word-of-mouth' diffusion should first of all, understand their socio-cultural value system, then convince them that they can be benefited by their experience with the film (see p.19 as well) and finally, motivate them to share their opinion with their online social circle.

Nevertheless, before using 'positive word-of-mouth' as a marketing tool one should consider some key principles and limitations, such as the fact that not all social networks and individuals have the same influence, hence, the marketing strategy needs to be destined for certain social platforms and specific target-groups and that positive word-of-mouth' can only happen in a specific environment under certain conditions, which can as well change rapidly [Allsop et al., (2007), pp.399-405]. 


\section{Four cases of marketing art house films via new age media platforms and services}

The marketing campaigns of the films 'Chevalier' (Tsangari, 2015), 'The Lobster' (Lanthimos, 2015), 'The Eternal Return of Antonis Paraskevas'; (Psykou, 2013) and “Attenberg" (Athina Rachel Tsangari, 2010) - as stated earlier - apart from the standard online marketing practices, such as the creation of an official website or an official Facebook page with information relative to the films' premier dates, attempt to take advantage of the potential offered via social media platforms for interactive participation and rapid expansion of information in order to develop their audience. What is more, it is strikingly interesting that two of them ('Chevalier' and 'Attenberg') take it one step further and incorporate traditional marketing mediums, such as print advertising, into a social media promoting scheme, in order to seize the benefits from both new age and more mainstream marketing tools. In the next pages, our analysis will focus on the design and characteristics of these marketing acts in relation to audience development and engagement.

\subsection{Instagram contest: Chevalier}

On the 19th of November 2015, the online newspaper LIFO launches a contest regarding the film Chevalier (Chevalier's Heroes are the Best. What about you?, 2015). The film is about six men on a fishing trip that decide to play a game which can only end when the 'best' player is announced (LIFO Team, 2015). The readers are invited to post photographs of themselves pretending to be one of the film's leading characters on the suggested Instagram page by using the tag \#Bestingeneral (https://www.instagram.com/explore/tags/bestingeneral/) and \#kaliterosgenikotera (https://www.instagram.com/explore/tags/kaliterosgenikotera/). As an incentive for participating in the contest, presents relative to the film - a poster and an invitation to a private film screening - are offered.

There is first and foremost an obvious connection with the film's plot, as the audience is invited to take part in a somewhat similar 'game' to that of the film. The high level of interaction makes them feel like being a member of the cast. The first step that a contest-participant must take is to familiarise with the main characters of the film and select one of them to impersonate. There is a story being told in each and every poster depicting one of the leading actors. A narrative is created through mental stimulations with the audience not only empathising with the film's characters through narrative transportation, but also imagining the film's plot [van Laer, (2019), p.136] leading to a higher degree of engagement ( $\mathrm{Ra}$ et al., 2018) and a stronger persuasive effect of the marketing strategy [Escalas, (2004), p.45].

Each one of the six Greek film posters created for this marketing strategy introducing a different character is comprised of a photograph of one of the protagonists as a visual message and a verbal message describing the personality of the character that is depicted in the photo. The same description accompanies each poster cited in the article with a Facebook and a Twitter tag in order for the readers to share the photos and information about the contest with their online social circle: 
Figure 1 Images of posters (see online version for colours)

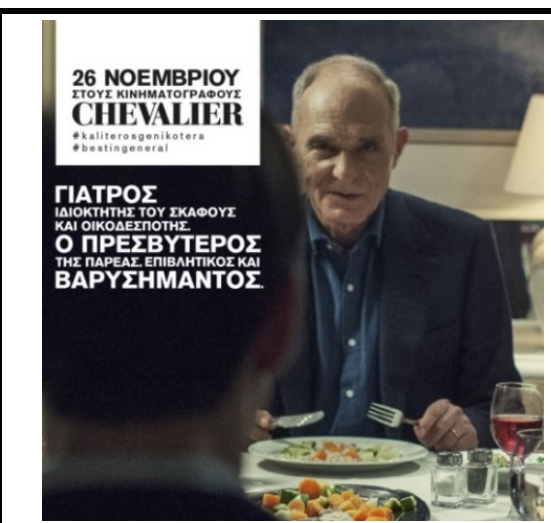

Doctor (Yiorgos Kentros): The owner of the boat and the host. The oldest of the group. Imposing and important.

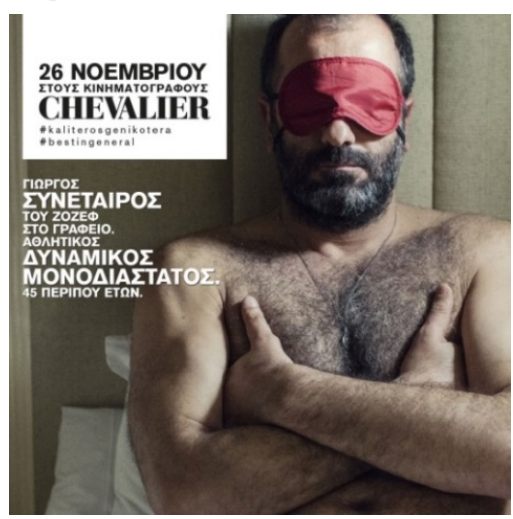

Yiorgos (Panos Koronis): Partner of Zosef in the office. Athletic, dynamic, one-dimensional. Approximately 45 years old.

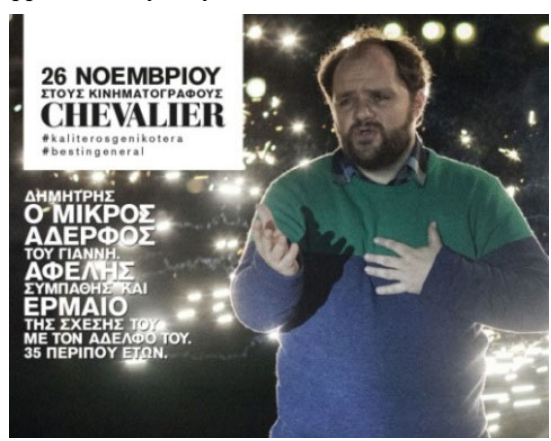

Dimitris (Makis Papadimitriou): The younger brother of Yiannis. Naïve, likeable and adrift of his relationship with his brother. Almost 35 years old.

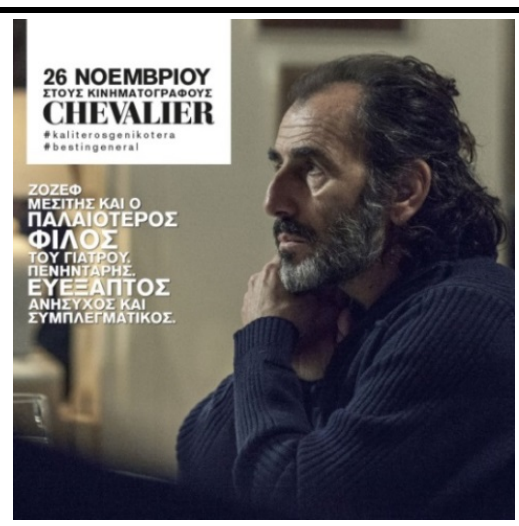

Josef (Vaggelis Mourikis): Real estate agent and the oldest friend of the Doctor. Middle-aged. Short-tempered, restless and full of complexes.

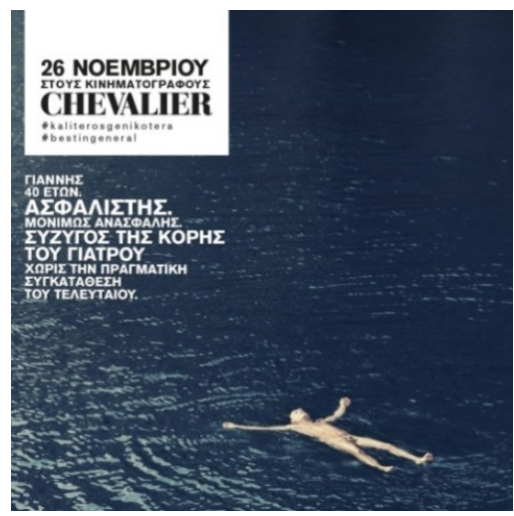

Yiannis (Yiorgos Pirpasopoulos): 40 years old. Insurance agent. Always insecure. Husband of the doctor's daughter without the actual consent of the latter.

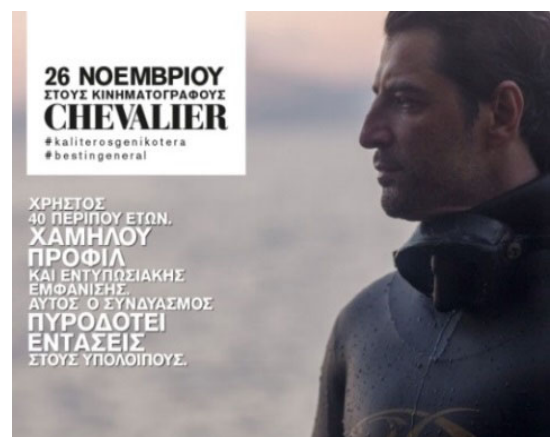

Christos (Sakis Rouvas): Almost 40 years old. A low profile character with an impressive appearance. This combination triggers intensive reactions among the rest of the group.

Source: LIFO Team (2015). 
At this point, the embracement of a traditional marketing tool - the poster - in a new age media marketing strategy attracts the attention. Despite being a static marketing medium, the poster's marketing value is undeniable due to its sheer commitment to its advertising objective(s), "It exists solely to display an advertising message. It has a single, specific purpose." (Parry, 2011). Film posters are designed and destined to communicate the essence of the film- its gender, its plot and all its unique elements - in order to 'sell' it as a 'must see' product and position it correctly in the mind of the reader, so that his expectations are met when he actually sees it [Kerrigan, (2010), p.129]. Furthermore, their unique ability to penetrate into audiences' daily routine, placed in strategic locations, such as in metro and railway stations, makes them an ideal marketing tool for audience development [Sifaki and Papadopoulou, (2015), p.476].

However, in this case, it is strikingly interesting that the poster's marketing journey is extended beyond the audience's offline activities, claiming its place in their everyday online social routine. The media user can either see the poster offline and be directed to the Instagram contest, or see the poster online for the first time in the newspaper article or the film's Instagram page. No matter where the first encounter takes place it makes little difference since the outcome is always the same; the poster has claimed a strong presence in the audience's online and offline daily routine acting as a constant reminder and hence, empowering its persuasive dynamic. The user can hopefully be encouraged to seek more information about the film and why not, participate in an interactive game. The poster is afresh appointed a new marketing role, exceeding the boundaries of a static marketing medium, as it can now be incorporated into a new social media marketing practice.

After 'getting to know' the film characters, Instagram users are encouraged to take a selfie in order for them to take part in the contest and eventually be rewarded. The use of selfies and snapshots is not an uncommon marketing practice, especially in branding campaigns. They can add value to a product not only because of displaying a high degree of authenticity and truth, but also by demonstrating how the product can be incorporated in our lifestyle (Iqani and Schroeder, 2016). The characteristics and values of the product, in our case the film, are transferred from the screen to the audience's daily online life. Selfies have to do much about how one see himself or how he aspires to be seen by others. By embodying one of the characters of the film, the values and traits of this character and the whole systemic value of the film finds its way into the audience's online daily communication. The selfies are uploaded and shared alongside with bits of information about the film, reaching different audience segments.

Finally, one cannot help but comment upon the marketer's effort to offer participation incentives, such as, the prizes for the winner and the variety of film stars and film characters for the social media users to choose from, in order to maximise audience engagement. Furthermore, due to the different educational and professional background of the six film stars a variety of fan communities can be targeted (Sakis Rouvas is a famous pop star singer with a huge teenage and female fan club, whilst Makis Papadimitriou is a well know comedian actor and Vaggelis Mourikis is an actor that has starred in many drama art house films productions). In fact, the engagement of fan communities can be also characterised as an excellent idea of 'crowdsourcing'. The marketers are enabled to reach audience segments that would be otherwise impossible for them to do so and appoint to the fan community, due to lack of funding, the role of the film's marketer [Kafoury, (2013), pp.25-26]. All the perquisites (Howe, 2009) do exist for a perfect example of a fan community 'crowdsourcing', even if it can only be assumed that it was not intentionally orchestrated as such. The equipment needed is 
available to all the users (a webcam or a mobile cam), there is online space for them to host their self-portraits, there are constant posts on the Instagram page about the premieres and the actors in order to promote the film and finally, the intention is to gather a great deal of information in one 'place' in order to attract users attention and spread information regarding the film.

Nonetheless, despite the prizes offered as participation incentives and the already existing fan community comprised of the actors' personal fan clubs and Athina Rachel Tsangari's previous films, only one photo was uploaded on the film's Instagram page. What is even more interesting though, is the fact that the article received 1,434 Facebook and Twitter shares (last accessed 2018 May 23), which means that there was indeed interest from the audience not only to be informed about the film and the contest, but also, to spread this information to their online social circle, but there was no interest in taking part in the contest, whatsoever.

\subsection{In search of the missing leading character: The Eternal Return of Antonis Paraskevas}

On the 19th of December 2013, an interactive Facebook (https://www.facebook.com/ AntonisParaskevas.TV) and Twitter (https://twitter.com/ReturnAntonisP?ref_src= twsrc\%5Etfw) promotion scheme for the film 'The Eternal Return of Antonis Paraskevas' is launched. Social media users are invited to 'find' the missing leading character of the film, Antonis Paraskevas, a famous TV presenter, who stages his own kidnapping in order to revive his career and bring himself once again to the limelight (Dalton, 2013). The leading actor of the film (Christos Stergioglou) brings Paraskevas into real life and an online social media 'search' for the missing TV presenter commences, with online articles, interactive social media games and YouTube video uploads. The fact that the whole social media marketing campaign revolves around the film's leading actor-character is not surprising though, as it is a common practice in independent film productions. Mainly due to lack of funds but also, due to the "characterdriven' storyline of this kind of films, actors are often recruited to help boost the film's publicity [Erickson, (2008), p.139].

The audience can enter the story from five different online 'gates', all of which are not only interconnected to each other, but also, lead to the very same YouTube video. The first entry points are Antonis' 'own' Facebook (https://www.facebook.com/ AntonisParaskevas.TV/) and Twitter page (https://twitter.com/returnantonisp), via which the character becomes 'a real person'. In fact, Antonis' Facebook page includes personal information about him in order to support the 'truthfulness' of his existence, such as, date of birth, personal interests, posts about his personal life and magazine covers. The character becomes alive through social media platforms; he is a famous persona that almost everyone has all heard, seen or read about in tabloids at some point. There is a link on both the Facebook and the Twitter page, through which the audience can be directed to a posted YouTube video launched on $19^{\text {th }}$ December 2013, featuring a news bulletin about Antonis' disappearance, just a month before the film's official Greek premier (23 January 2013) (The News Bulletin About Antonis Paraskevas' Disappearance, https://www.youtube.com/watch?v=RgZ5EaULDUI\&feature=youtu.be).

On the very exact date with the YouTube video's launch, the 'news' about Antonis' disappearance 'hit the headlines' in two online articles, one in the online magazine 'Flix' (http://flix.gr/news/ektakth-eidhsh-eksafanisthke-o-antonhs-paraskeyas.html) and the 
other in the online newspaper 'in.gr' (http://news.in.gr/perierga/article/?aid= 1231282130), both of which include a link to the same YouTube video and to 'Antonis' Facebook and Twitter page. Finally, the last - obvious to be mentioned - entry point is the YouTube platform, from where the audience can watch the video, interact with it, embed it and then, share it with their online social circle via eleven different social media platforms (Facebook, LiveJournal, ВКОНТАКТЕ, Одноклассники, Google+, Blogger, Twitter, reddit, Tumblr and Pinterest).

The video has a 44-minute-duration and it is supposed to be an abstract from a news bulletin featuring the breaking news of Antonis' disappearance and his last TV appearance on his show. The campaign is designed in such a way that no matter from which entry point the audience will access the story, they will still end up seeing the YouTube video, as YouTube content is destined to be spread (Usher, 2010) and it can help the 'news' become viral.

Figure 2 Graphic showing points of entry to the contest and how they are connected

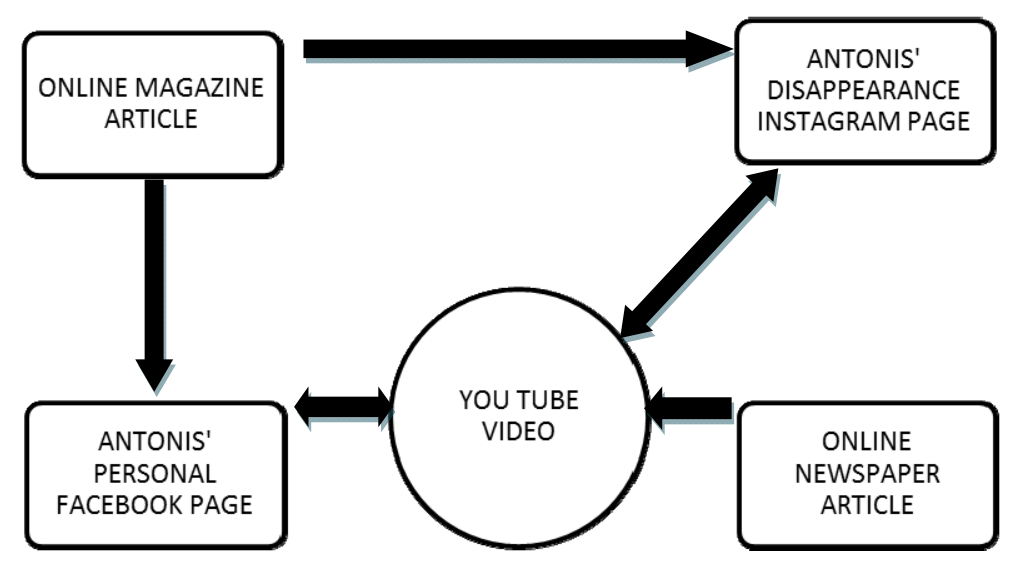

After the upload of the first YouTube video the 'search' continues and the suspense is intensified with a barrage of videos uploaded on his Facebook page (until January the 8th) with links directing users to view them on YouTube, featuring famous Greek personas, such as actors, TV presenters, singers, film critics, politicians, talking about Paraskevas and his disappearance as if it were real. The number and frequency that the videos are uploaded alongside with key bits of information revealed about the film are intensified as the film's premier date approaches, which is actually a quite common practice in 'transmedia' marketing storytelling [Kafoury, (2013), p.30] in order to add fuel to the audience's anticipation for the official premier. When, at last Paraskevas makes himself appear again, a video is anew posted on both Facebook and Twitter with a direct link to a YouTube trailer, featuring Paraskevas talking about his reappearance and inviting the audience to the official film premier on the 23rd of January. This can be of course acknowledged as the first official trailer of the film, since after watching Paraskevas talking, the video ends with the film's title, the date of the premier and the name of the producer (Antonis Paraskevas Announces his Return, https://www.youtube.com/watch?v=0bSlMbhp6g0\&feature=youtu.be). Once again, following the previous pattern, new videos of Greek personas are uploaded talking about his return. 
Contrary to what one would expect, this marketing act does not stop with Antonis' reappearance. A new interactive game between him and the social media users is launched. Four videos are posted on his Facebook page with four - related to the film's title - words, 'eternal', 'return', 'Antonis', 'Paraskevas'. The actor provides each word as a stimulus for the audience to produce word associations. Sadly, the audience response is minimum, as no word-associations are posted under each video. The only interaction that appears to have taken place is some 'likes' varying from a minimum of 18 to a maximum of 29 (last accessed 26 April 2018).

Upon making our final remark, a legitimate inquiring results us to wonder whether this new age media marketing strategy has the perquisites to be considered as a 'transmedia' storytelling, according to Jenkins (2007), or it is simply a case of crossplatform marketing. The focal point of the story is actually the character himself and his personal agony to return once again to the spotlight. The narrative key bits have been scattered mainly across three different media platforms, Facebook, Twitter and YouTube. The users are appointed a specific task (role), that of finding the 'missing' character and in doing so, the fictional story is transferred in the audience's everyday life. The intention of interacting with the audience does exist. The users can embed and share the YouTube video with their online friends or take part in the words- game. However, there is still a long distance to be covered in order for this strategy to be acknowledged as 'transmedia' marketing. To begin with, each of the three mediums does not contribute evenly with different key bits of information in order for a fictional universe to be completed, but the exact same video is uploaded in all of the platforms. Furthermore, the information provided to the audience is just handed to the audience, with no actual intention to draw them into any kind of interaction among them, apart from 'spreading the word'. They are invited to search for the missing character but it is indeed a 'fake' invitation. There is not any kind of game or searching. They don't contribute in any way to the creation of the world; they do not engage themselves into any kind of interaction. Perhaps this is why the audience's response was so disappointing with only few Facebook 'likes' ranging from 22 to 44 'likes' and merely three 'likes' and two 'dislikes on the YouTube platform trailer (last accessed 26 April 2018).

\subsection{Internet quiz game: The Lobster}

In 'The Lobster' official website the audience is invited to answer ten personal questions in order to 'discover' the animal they will be transformed into, in case they fail to fall in love (http://thelobster-movie.com/). There is an obvious connection with the film's plot, in which the leading characters are forced to stay in 'The Hotel' due to having no life partner in order to either fall in love or be transformed into an animal of their choice in case they fail to do so (The Lobster, 2015). After having completed the questionnaire the user ends up with three animal choices, having to choose only one of them. He can then download or share the outcome of the questionnaire with his online friends by posting it on his personal Facebook or Twitter page, or be directed to the official Facebook and Twitter film's page, where there is also a link back to 'The Lobster' official website. That means that the test taker can enter the story from three different points, the official website, the official Facebook page and the official Twitter page and still end up filling the questionnaire. 
Figure 3 Graphic of the 'Lobsters' entry points

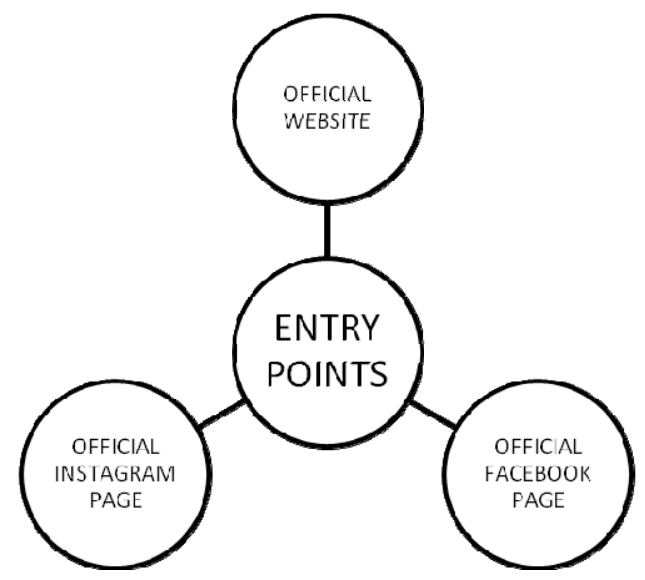

A main distinction from the previous marketing strategies is that this one seems to be destined to an international audience given that it is also an English speaking film. The 'Lobster' questionnaire is solely subjected to social interaction in order for it to fulfil its marketing purpose. Based on the principal "If it doesn't spread, it's dead", its circulation and distribution rests upon the audience. According to Henry Jenkins, the purpose is to 'make it their own' and spread it to their inner social circle (Usher, 2010). With the title 'The website that determines your second chance animal' and the quote:

"If you fail to fall in love (or stay in love) with another person, you'll be given a second chance as an animal. You will need to choose your second chance animal carefully. The following test will help determine what options are best for you (best on your personality, psychology, and defining characteristic),"

the journey begins. The words 'second chance', 'choose', 'test' have been chosen to be cited in bold, conveying the purpose of the questionnaire if one reads it independently from the rest of the quote. The questionnaire is comprised of ten questions.

As already mentioned, after completing the questionnaire, the user is faced up with three animal options, from which he has to choose only one to be transformed into, in case he does not find his true match. There is a warning though, "Please choose carefully. This decision is final".

The first observation to be made is that the audience are not only able to spread information relative to the film provided by the producer, but they can also embrace it, create new information - even though their freedom of choice is limited, since they end up only among three animal options - and share it across other media platforms with their online social circle. Once again (as in Chevalier) the audience gets acquainted with the film's fictional space and puts himself in the shoes of the characters. They are immersed into the plot, facing both personal and fictional dilemmas. Furthermore, they cannot only share this experience with other social media users, but also indulge them into taking part in the online quiz. 
Figure 4 Lobster's questionnaire

\begin{tabular}{|c|c|c|}
\hline 1 & Housecats should not kill birds. & \\
\hline & ○ Neutral & ○ Disagree \\
\hline \multirow[t]{2}{*}{2} & \multicolumn{2}{|c|}{ I prefer to dance with someone, alone or I don't dance. } \\
\hline & $\circ$ With someone & $\circ$ I don’t dance \\
\hline 3 & \multicolumn{2}{|l|}{ Bad eyes or bad legs. } \\
\hline 4 & \multicolumn{2}{|c|}{$\begin{array}{l}\text { Small room with large windows and a view or large room with small windows and no } \\
\text { view. }\end{array}$} \\
\hline 5 & \multicolumn{2}{|l|}{ We all die alone. } \\
\hline & \multirow{2}{*}{\multicolumn{2}{|c|}{$\begin{array}{l}\text { True } \\
\text { Sexual preference. }\end{array}$}} \\
\hline 6 & & \\
\hline & \multicolumn{2}{|c|}{ Female } \\
\hline \multirow[t]{2}{*}{7} & \multicolumn{2}{|c|}{ What is the longest you have been in a relationship? } \\
\hline & $\circ 6$ months or less & $\circ 4$ years or more \\
\hline \multirow[t]{2}{*}{8} & \multicolumn{2}{|c|}{$\begin{array}{l}\text { There is a runaway train barrelling down the tracks. Ahead, there are } 17 \text { anonymous people } \\
\text { locked in a bus, stuck on the tracks. They are unable to escape and the train is headed } \\
\text { straight for them. You are standing some distance off in the yard, next to a lever. If you } \\
\text { pull this lever, the train will switch to a different track avoiding the collision. However, } \\
\text { you notice that a member of your family is tied up on the other track. What do you do? }\end{array}$} \\
\hline & ○ Nothing & lever \\
\hline 9 & \multicolumn{2}{|c|}{$\begin{array}{l}\text { What do you see? (A sketch is provided with the indication: "one word please". The test } \\
\text { taker has to write what he think the sketch is) }\end{array}$} \\
\hline 10 & \multicolumn{2}{|l|}{ Did you answer the question truthfully? } \\
\hline & $\circ$ Yes & \\
\hline
\end{tabular}

Apart from the high degree of expected interaction analysed in the previous paragraph, the emotional stimulation that this marketing act is based upon can also lead to its becoming viral (Dobele et al., 2007). On a first level, the questionnaire can be viewed as a clear showcase of 'emotional branding', in the way that Marc Cobe attempted to define it, by acknowledging the marketing value of emotions in a marketing strategy, which can lead to raising audience awareness and to an increase in sales through the emotional empathy with a product [cited in Ulrike, (2002), p.25]. On a second level, apart from the personal identification of the audience with emotions, such as fear and love, the luring value of this marketing scheme is reinforced by the need of the audience after a strong emotional experience to share it with their social circle. The stronger the intensity of the emotion they have experienced is, the more likely it is for that emotion to be wanted to be shared repeatedly and with multiple recipients [Rimè, (2007), p.308]. In this case, emotionally charged words or phrases such as, 'kill' or 'we all die alone' alongside with strong personal dilemmas, like the one in question number 8 , can certainly enable the facilitation of interaction among social media users. Undoubtedly, the questionnaire can evoke high degree of anticipation to the test taker, since it is destined to diagnose the personality traits that he shares with the very same animal that he will be transformed into in case he fails to fall in love. It actually 'warns' the test taker that this decision is 'final' and once it is made it cannot be undone. In fact, the anticipation becomes more intense when the user shares the outcome with his online friends and awaits to see whether they have the same result or not. 
Nonetheless, at this point one cannot help but note that prior experience with the film is required in order for someone to fully comprehend the core of the quiz. Is this promotional strategy destined to appeal only to the audience that has already seen or at least heard about the film? Partly, yes. They need to have some knowledge in order to understand both the purpose and its outcome, as each and every question is closely related to the film's plot. In any case, it wouldn't be an overstatement for someone to say that the audience would never have bothered to search for the film's website and discover this quiz, if they had not previously seen or at least heard about the film. Therefore, it can be deduced that the purpose of the quiz is to solely encourage interaction with the audience that is already familiar with the film in such a way that will boost its promotional speed and magnitude.

\subsection{Attenberg on the Streets: Attenberg}

Through the film's official Facebook page the audience is invited to photograph and post the Attenberg print advertisements he encounters in his everyday life (http://www.facebook.com/attenberg/). With the tag 'Attenberg on the Streets' an interactive promotional scheme is launched encompassing traditional and new media marketing practices. Once more the dynamic of print advertising, such as the poster, meets new age social media. Users from different countries respond by posting photos of print advertisements placed in metro stations, on the streets and in magazines. It is a chance for print advertising to re-establish its one way relationship with the receiver 'viewer' of the advertising message and be incorporated into a marketing strategy that envisages less controlled, more truthful and more engaging marketing practices acknowledging the possibilities offered in a new digital era [Deighton and Kornfeld, (2007), p.2]. The reader can now become a marketer; the door to enter this new age media storytelling can be found anywhere, on condition that he has access to an electronic device.

The first observation to be made is that this strategy is based on the fact that social media users are drawn by the urge to form online social groups with common interests and values [Mangold and Faulds, (2009), p.361]. In the case examined, an online community is attempted to be formed according to the parameters, rules and restrictions set by the 'sender', in order for him to define in a very specific way its target audience. This strategy appeals to an international niche audience on the grounds that the language that is used to communicate is the English language and the film itself has had an international appeal in film festivals around the world (Sifaki et al., 2016). Furthermore, it is destined for an audience, who presumably has an interest in photography and more traditional communication mediums, but who also chooses to engage into some kind of social media interactivity. In order to secure a loyal fan base, the producers aim at creating a virtual group with members that are likely to share information about the contest and the film. In that way, the film's reputation is spread through the relationship established among social media users with shared interests that are more than willing to upload and share their contest-photos or engage into relevant to the contest conversations [Paliszkiewicz and Koohang, (2016), p.56].

In this case - opposed to the 'Chevalier' promotional act, where social media users were given the opportunity to be immersed into the fictional world of the film - the audience is invited to capture how the film via print advertising has become a part of their daily realm. The 'Attenberg' posters (see images below) are designed in such a way as to 
transfer the attributes of the film, such as, the emphasis placed on sexual awakening, the realm of senses and the body itself [Nikolaidou and Poupou, (2017), p.94] in a more intellectual concept (Hoeij, 2010). They can be emotionally engaged with the film's attributes in such a degree that they become part of their reality. However, in order for the marketers to overcome the obstacle of the one way relationship aroused by traditional advertising mediums and establish a new, two-way communication with their audience, they give them the opportunity to stage their own 'digital poster' in only one condition; to include in them one print advertising material of the film. The poster is afresh given another role, it becomes the springboard to the creation of a brand new image, which captures a moment of the users' lives; the moment they encounter 'Attenberg'. The audience's opinion matters. Their feedback is important to the people that designed this marketing strategy and to other online like-minded social groups.

Unfortunately, once again this promotional scheme is met with poor participation, since only five photos were posted on the film's official Facebook page (see Figure 5). The reason can presumably be found in the fact that this kind of use of the social media especially Facebook - is not usually met in marketing film products, but it has for long been put down to practice by major cultural organisations, in order for them to broaden their audience and establish a more interactive relationship with it (Gonzalez, 2017). Social media platforms and services can be used both ways, prior to the audience's experience with the cultural product or after. In the first case, the goal is simply to create an audience before the big day (Giridharadas, 2014), when the cultural product is introduced for the first time to the audience. In the latter case, a feedback is encouraged in order for the audience to share their overall impression with their online circle. However, even though a museum's audience and experience is much different than that of a film's, the reason for the disappointing participation in this promotional act, should not be sought there. It rests upon timing. When the audience is encouraged to take photos of their experience in a museum, it is usually done while they are still there, whether they are wandering around an exhibition or right after they have seen it, but hopefully still being at the premises, so that any kind of emotions and excitement is shared while they are still 'fresh'. In fact, there are available apps that help cultural institutions "create a visual story" combining the exhibits on the display and the visitors experience in order for a strong bond to be created between the institution and the audience based on their active involvement in the museums activities. However, in our case, the audience was asked to take photos long after they have seen the film, or even worse, before having seen the film at all with no incentives offered, whatsoever. In the first case, since no incentives were offered, it is highly unlikely that someone would have taken the time to engage into interaction, since a substantial amount of time would have passed from the moment that he had seen the film; therefore, any emotions experienced would have probably faded away. In the latter case, engaging an audience into interaction before having seen the film, would have probably needed the existence of a loyal fan base of the director or the actors, which unfortunately does not apply to our case since 'Attenberg' was the first film that Tsangari had written and directed herself and the actors were not particular popular at the time. 
Figure 5 Photographs participating in Attenberg's Facebook contest (see online version for colours)

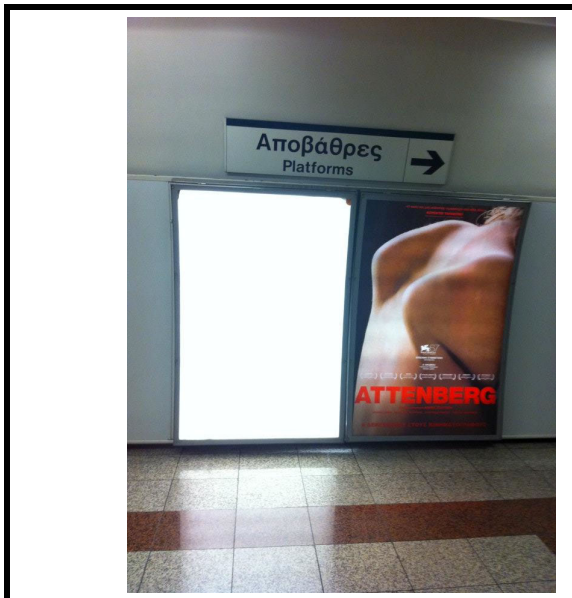

Photograph 1. On the Athens Metro, Greece (Karseras, 2011)

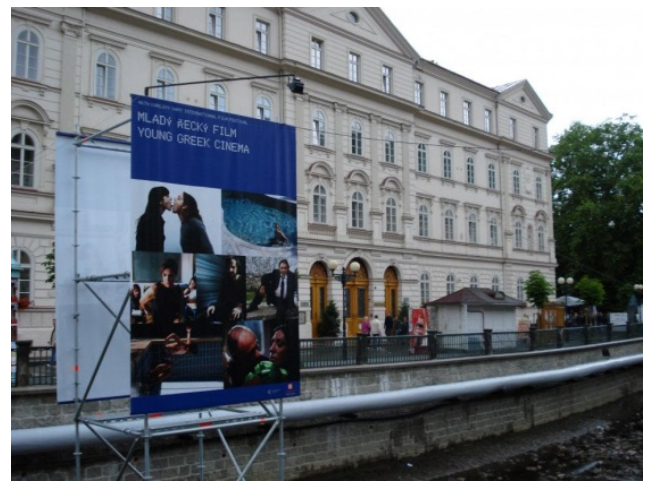

Photograph 3. On the streets of Karlovy

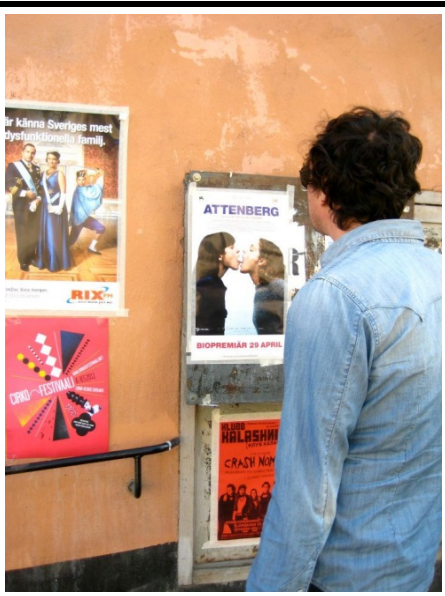

Photograph 2. On the Streets of Sweden (Etten, 2011)

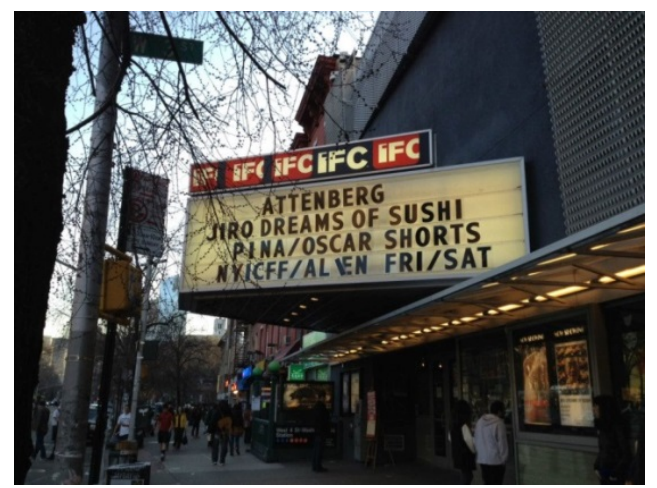

Photograph 4. At the IFC Center, New York (David Barker, 2011)

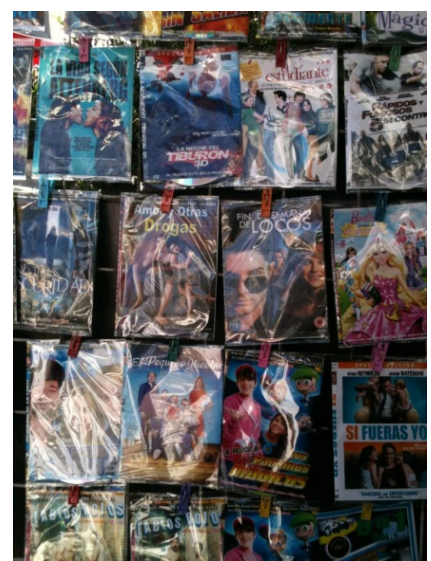

Photograph 5. On the streets of Mexico, 'Life According to ATTENBERG' (Bani Khoshnoudi, 2011) 


\section{Discussion}

Today, digital media platforms have empowered individuals and peripheral groups to challenge social structures, power balances and prominent institutions (Kyprianos et al., 2019). When Henry Jenkins talked about media 'convergence' he intended to define and acknowledge the genesis of a new era, where the emergence of new social media platforms fosters not only the rapid flow of information, but also the 'migratory behaviour' of social media users seeking to explore new ways to entertain themselves [Jenkins, (2006), p.2]. New media platforms and services have taken media participation a step further, from the controlled interaction among media-users to the active participation in a film's production, distribution (p.133) and promotion.

Following the semantic analysis of four new age digital marketing acts of art-house European films destined to appeal to a niche art-house audience, in a sense that their market share was already somewhat 'restricted', our effort to evaluate their outcome is not an easy task. The success of new age media marketing does not lie in numbers, but in the sentiment and the interactive relationship achieved between the producer and the targeted audience [Brown, (2012), p.14]. Nevertheless, an attempt will be made to evaluate their appeal based on the documented interaction of social media users, including data such as, 'likes' and photo uploads (see below) and their design and implementation in reference to the specific characteristics of an art house audience. Special insight will also be given to the way that more traditional and static advertising mediums, such as the poster, can be incorporated into new age media marketing strategies.

The first observation to be noted is the fact that all four marketing acts examined were designed with a view to convey the essence and the values of the film. Its high artistic and avant-garde features together with the attributes of its main characters were bestowed to pass on to the audience. The intention was to encourage the audience's identification and emotional engagement with the films' characters, main values and personal dramas in order for the films to find their way into the audience's realm. Characters 'become alive' through the interactive 'Chevalier' contest and the 'disappearance' of Antonis Paraskevas; values and emotions, such as the agony for eternal love and fear of loneliness, are transferred from the film to the audience's realm when taking the test in 'The Lobster' questionnaire; and lastly, an open invitation is handed down to any Facebook user that wishes to capture in a 'photo' how that avant garde aesthetics and the intense sexuality of 'Attenberg' has found its place in his daily routine.

Nevertheless, it seems that despite the intensity of the emotions entangled in the strategies and the opportunity for the social media users to share their personal emotional experiences with their online friends, these marketing actions failed to adequately indulge them into any kind of interaction or 'positive word-of-mouth' diffusion. In fact, as presented below, it is even more interesting that the social media platforms employed in these marketing campaigns had thousands of visitations, but there is no documented interaction whatsoever. 
Figure 6 Data regarding social media response and interaction

SOCIAL MEDIA RESPONSE AND INTERACTION:

Chevalier Instagram Contest:

- 1 photo upload on the Instagram.

- 1,453 Facebook and Twitter shares of the online article.

The Lobster: We were not able to collect any data.

The Eternal Return of Antonis Paraskevas:

- 22 Facebook "likes" on the post about Antonis disappearance and 44 Facebook "likes" on the post about his reappearance.

- 18-29 Facebook "likes" on the teaser-trailers of the online word game.

- 2,102 users follow Antonis' personal Facebook page.

- 131 users follow Antonis' personal Twitter page.

- $\quad 8,447$ views and 3 "likes" of the breaking news about his disappearance on the YouTube platform.

Attenberg:

- 5 photo uploads on the Facebook page.

- 5,410 users follow Atenberg's official Facebook page.

(Data were last updated on the 26 April 2018)

More specifically, their design and implementation was clearly based on the audience's personal identification with the films' characters, values and dramas. They were given the chance to experience the feelings of loneliness, agony and love in 'The Lobster' questionnaire, the anguish for social recognition in the 'Chevalier' Instagram contest, the struggle to remain in the centre of attention caused by feelings of vanity and insecurity while 'searching' for 'Antonis Paraskevas' and the emotional drama of two young girls entering adulthood when they were asked to photograph 'Attenberg' in the streets. Taking into account the intensity of these feelings and the fact that the audience could have experienced such emotions at some point in their lives, one cannot help but wonder how and why the targeted audiences remained untouched and consequently, indifferent to engage into any kind of interaction. To begin with, one possible explanation would be that - according to research (Dobele et al., 2007) - emotions alone are not adequate enough to boost the vitality of a new age marketing campaign, unless they manage to intrigue, in some way, the recipient's interest or they are 'cleverly targeted'. Therefore, even though, for instance, 'The Lobster' campaign carried a strong emotional burden linked to the film's ethical dilemmas, its message was not considered worthy enough to be spread since it did not manage to attract the target audience's interest in a very memorable way. To put it simply, it was not 'catchy' enough for this specific target group, which reveals that no effort was made to define the specific characteristics of this particular niche audience so as to ensure the spreadability of the marketing message; and this is exactly the second reason to be addressed.

Naturally, in low budget independent films lack of funds is a hurdle in the whole life product circle, let alone in the marketing process. However, it is, in fact, this very same reason that makes it even more vital for small productions to undertake some kind of market research in order to build more interactive and deep relationships with the audience in order to have a better understanding of the targeted audience, and especially 
what motivates them to take part in a contest or what stimulates positive word-of-mouth; What are the social and individual values that spur this particular audience to think that they will gain some kind of benefit through interacting with the brand/sender? [Bilro et al., (2018), p.17]. Such knowledge can be obtained by collecting qualitative data from digital environments (such as, social media interaction or tags and posts in social media platforms), which can act as useful means to understand audience's behaviour, measure the effectiveness of current marketing strategies [Kannan and Li, (2017), p.38] and develop future ones. Therefore, a clear definition and understanding of the target audience is the key to a successful allocation of the available scanty funds and the creation of a final film product that is destined to appeal to a 'compatible target audience' (Ilott, 1996).

When designing and implementing a marketing strategy for a niche audience certain qualities should be taken into consideration, whether it is an offline or an online strategy. First of all, research has shown that art house audiences are more likely to be influenced by critics' opinion when choosing a film rather than a personal recommendation by their social circle [Austin, cited in Zaichkowsky et al., (2009), p.215]. Therefore, any kind of new age media strategy that relies upon social media interaction is possibly from the start doomed to fail, if based upon the audience to produce and spread word-of-mouth that will affect this kind of online community. What is more, again when having to do with a niche audience, marketers should take into account that such audiences are more likely to be influenced by elements such as, 'high quality' or even the name and previous work of the film's producer or director (p.215). What is strikingly interesting is that even though such elements were more than highlightened in the overall marketing strategy of the films, including posters, YouTube trailers, press kits etc. (Sifaki et al., 2016), they were - to our surprise - ignored in the examined digital marketing strategies. Last but not least, there could have been a better exploitation of the potentials offered by social media platforms and services for a better understanding of the targeted audience. Research has shown that there is a connection between ticket sales and new age media platforms and services, as far as art house audiences are concerned [Symeou et al., (2015), pp.740, 748]. Therefore, platforms, such as the YouTube, can be used in low budget independent productions as an inexpensive means of market research (though posted comments, likes and dislikes) and a useful tool to raise audience's awareness. In that way, they can lead to a better box office performance or at least to a much better estimation of it.

A last observation to be made is the employment of traditional advertising mediums, such as the poster, in two of the four marketing strategies explored in the article. The first one is the 'Chevalier Instagram Contest', in which posters of the film are incorporated in an online article in order for the audience to familiarise themselves with the film's plot and characters and act upon it through social media. In that way, the clear and strategically targeted message of the advertising poster is able to overcome the barriers of a static advertising medium and empower its luring and persuasive effect by exploiting all the potentials offered in the new digital era. In the case of the 'Attenberg on the Streets' marketing act though, not only the poster but all kinds of print advertising mediums were taken advantage of, as social media users were invited to upload print advertisements wherever and whenever they encountered them and in doing so they would have the opportunity to show how their reality affects the way they 'see' the advertising message, in other words, how the 'Attenberg' 'fits into' their realm, not the other way round. When one look at them, he notices not only the print advertising materials of the film, but also the user's living environment, his own reality; a building 
that the user may encounter every day on his way to work a or a metro station, where one lingers on a daily basis. In that way, each social media user was given the chance to become not only a 'marketer' - by uploading the advertisement and sharing it with his online circle- but also an 'artist'. He was able to create a new visual image offering his own viewpoint on how the 'Attenberg' has found its place in his surroundings in an offline, 'real' world. However, even with the synergy of both traditional and new age advertising media, these two particular marketing campaigns did not eventually work out to engage participation. Another possible reason for this deficiency can lie in the fragmented design and implementation of the whole marketing campaign by different producers and distributors for each country that the films were screened (Sifaki et al., 2016). Perhaps in the case of an international art house audience a more holistic and cohesive approach would have been more appropriate.

In retrospect, one can conclude that in the case of low budget art house film productions new age media platforms and services can be proven a useful and inexpensive tool for rapid expansion of information relatively to the film via positive word-of-mouth and social media interaction. However, from our research it has become more than clear that for any kind of interactivity to occur, as far as a niche audience is concerned, perquisites such participation incentives, fan culture development and audience research are more than necessary. In all of the four cases examined one can certainly acknowledge the producer's effort not only to encompass into these practices the essence, the aesthetics and the whole systemic value of the film but also, the intention to make the audience a part of their fictional world - or maybe one should better say their 'reality'. In doing so, ingenious online marketing practices were designed and implemented, in which new age and traditional media advertising mediums meet, advertising practices become a part of a social media strategy and social media users 'find their way into' a film through interactive participation. Nevertheless, these efforts weren't adequate enough to attract audience's attention and encourage interaction. Their poor participation rests upon their failure to have a complete image of their audience and encompass specific characteristics of viral marketing.

\section{References}

Akdeniz, C. (2015) Viral Marketing Explained, Can Akdeniz.

Allsop, D.T., Bassett, B.R. and Hoskins, J.A. (2007) 'Word-of-mouth research: principals and applications', Journal of Advertising Research, Vol. 27, No. 4, pp.398-411.

Barnwell, R.G. (2019) Guerrilla Film Marketing: The Ultimate Guide to the Branding, Marketing and Promotion of Independent Films \& Filmmakers, Taylor \& Francis, New York.

Berte, K., Vanhecke, K., Pelssers, J., Holvoet, W., Pessemier, T., Jans, G., Verbrugghe, V., Deryckere, T., Leroux, P., Martens, L., Turck, F., Demeester, P. and Bens, E. (2008) 'Advertising in a digital environment (ADME): an interdisciplinary approach to a usercentered advertising model for IDTV', Paper presented at the Workshop on Digital Television Revisited: Linking Users, Markets and Policies, 15-18 May 2018, Budapest.

Bilro, R.G., Loureiro, S.M.C. and Guerreiro, J. (2019) 'Exploring online customer engagement with hospitality products and its relationship with involvement, emotional states, experience and brand advocacy', Journal of Hospitality Marketing \& Management, Vol. 28, No. 2, pp.147-171.

Bourdaa, M. (2012) 'Transmedia: between augmented storytelling and immersive practices', INA Global [online] http://www.inaglobal.fr/en/digital-tech/article/transmedia-betweenaugmented-storytelling-and-immersive-practices (accessed 20 November 2016). 
Bourdaa, M. (2014) 'This is not marketing. This is HBO: branding HBO with transmedia storytelling', Networking Knowledge: Journal of the MeCCSA Postgraduate Network, Vol. 7 No. 1 [online] https://ojs.meccsa.org.uk/index.php/netknow/article/view/328 (accessed 1 December 2019).

Brown, E. (2012) Working the Crowd: Social Media Marketing for Business, 2nd ed., BCS, UK.

Cone, S. (2008) Powerlines: Words That Sell Brands, Grip Fans, and Sometimes Change History, Bloomberg Press, New York.

Dalton, S. (2013, August 09) 'The eternal return of Antonis Paraskevas: Toronto review', The Hollywood Reporter [online] https://www.hollywoodreporter.com/review/eternal-returnantonis-paraskevas-toronto-623714 (accessed 1 December 2019).

Deighton, J.A. and Kornfeld, L. (2007) Digital Interactivity: Unanticipated Consequences for Markets, Marketing, and Consumers, Unpublished Working Paper, Harvard Business School, Boston MA [online] http://www.hbs.edu/faculty/Publication\%20Files/08-017_1903b556786c-49fb-8e95-ab9976da8b4b.pdf.

Dempsey, C., Guiney, E., Lanthimos, Y., Magiday Lee (Producers) and Lanthimos, Y. (Director) (2015) 'The Lobster' [Motion Picture], Ireland/UK/Greece/France/Netherlands: Film4, Irish Film Board, Irish Film Board, Eurimages, Nederlands Fonds voor de Film, Greek Film Centre, British Film Institute [online] http://www.imdb.com/title/tt3464902/.

Dobele, A., Lindgreen, A., Beverland, M.B., Vanhamme, J. and Wijk, R. (2007) 'Why pass on viral messages? Because they connect emotionally', Business Horizons, Vol. 50, No. 4, pp.291-304 [online] https://orca.cf.ac.uk/42783/1/Article\%2016.pdf (accessed 1 December 2019).

Du Plessis, C. (2018 January 9) 'Prosumer engagement through story-making in transmedia branding', International Journal of Cultural Studies, Vol. 22, No. 1, pp.175-192, DOI.org/10.1177/1367877917750445.

Eisenhardt, K.M. (1989) 'Building theories from case study research', Academy of Management Review, Vol. 14, No. 4, pp.532-550.

Erickson, M.P. (2008) 'Co-opting independence: Hollywood's marketing label', in Sickels, R.C. (Ed.): The Business of Entertainment, pp.129-152, Praeger, US.

Escalas, J.E. (2004) 'Imagine yourself in the product: mental simulation, narrative transportation, and persuasion', Journal of Advertising, Vol. 33, No. 2, pp.37-48, DOI:10.1080/00913367.2004.10639163.

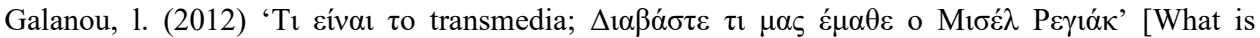
Transmedia? Read about what we have learned by Michel Reilhac], Flix [online] http://flix.gr/articles/transmedia-o-misel-regiak-milhse-sto-ifa-gia-th-ne.html (accessed 1 December 2019).

Giridharadas, A. (2014) 'Museums see different virtues in different worlds', The New York Times [online] https://www.nytimes.com/2014/08/08/arts/design/museums-see-different-virtues-invirtual-worlds.html (accessed 1 December 2019).

Godes, D. and Dina, M. (2004) 'Using online conversations to study word-of-mouth communication', Marketing Science, Vol. 23, No. 4, pp.545-560.

Gonzalez, R. (2017) 'Keep the conversation going: how museums use social media to engage the public', The Museum Scholar, Vol. 1, No. 1 [online] http://articles.themuseumscholar.org /vollnolgonzalez (accessed 1 December 2019).

Hardy, J. (2010) Cross-Media Promotion, Lang Publishing, New York.

Hatzakou, M. and Konstantakopoulos, Ch. (Producers) and Tsangari, A.R. (Director) (2015) Chevalier [Motion Picture], Greece: Faliro House Productions, Greek Film Center, Haos Film [online] http://www.imdb.com/title/tt3526706/.

Hoeij, V. (2010) 'Attenberg: the impressive sophomore feature of Greek scribe-helmer Athina Rachel Tsangari', Variety [online] http://variety.com/2010/film/markets-festivals/attenberg1117943531/ (accessed 1 December 2019). 
Howe, J. (2009) Crowdsourcing: Why the Power of the Crowd Is Driving the Future of Business, Three Rivers Press, United States.

Ilott, T. (1996) Budgets and Markets, A Study of the Budgeting of European Film, Routledge, London.

Iqani, M. and Schroeder, J.E. (2016) '\#Selfie: digital self-portraits as commodity form and consumption practice', Consumption Markets \& Culture, Vol. 19, No. 5, pp.405-415 [online] http://www.tandfonline.com/doi/full/10.1080/10253866.2015.1116784 (accessed 1 December 2019).

Jenkins, H. (2003) 'Transmedia storytelling: moving characters from books to films to video games can make them stronger and more compelling', MIT Technology Review [online] https://www.technologyreview.com/s/401760/transmedia-storytelling/ (accessed 1 December 2019).

Jenkins, H. (2006) Convergence Culture: Where Old And New Media Collide, New York University Press, New York.

Jenkins, H. (2007) 'Transmedia Storytelling 101', Confessions of an Aca Fan [online. http://henryjenkins.org/blog/2007/03/transmedia_storytelling_101.html (accessed 1 December, 2019).

Kafoury, M.F. (2013) Transmedia Cohesion in Motion Picture Advertising. Communication, Honors Theses, Trinity University, San Antonio, Texas [online] $\mathrm{http}$ ://digitalcommons.trinity.edu/cgi/viewcontent.cgi?article=1008\&context=comm_honors (accessed 1 December 2019).

Kannan, P.K. and Li, A. (2017) 'Digital marketing: a framework, review and research agenda', International Journal of Research in Marketing, Vol. 34, No. 1, pp.22-45.

Kerrigan, F. (2004) 'Marketing in the film industry', in Kerrigan, F., Fraser, P. and Özbilgin, M. (Eds.): Arts Marketing, pp.26-41, Elsevier Butterworth-Heinemann, Oxford.

Kerrigan, F. (2010) Film Marketing, Elsevier Ltd., Oxford.

Kitsopanidou, K. (2014) 'Building a brand through transmedia audience engagement strategies: Avatar's transmedia marketing', Médiation \& Information. Revue Internationale de Communication, No 39, pp.115-135.

Kyprianos, K., Sifaki, E. and Bantimaroudis, P. (2019) 'Digital gatekeepers and website visitors of the Acropolis Museum: revisiting gatekeeping theory in the cultural domain', Museum Management and Curatorship, pp.1-15, doi.org/10.1080/09647775.2019.1630851.

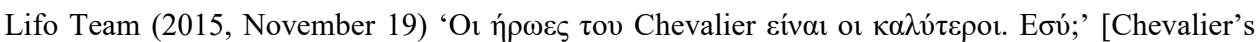
Heroes Are the Best. What About You?], [Chevalier's contest launch] LIFO [online] http://www.lifo.gr/market/marketnews/81238.

Liu, Y. (2006) 'word of mouth for movies: its dynamics and impact on box office revenue', Journal of Marketing, Vol. 70, No. 3, pp.74-89.

Mangold, G.W. and Faulds, D.J. (2009) 'Social media: the new hybrid element of the promotion mix', Business Horizons, Vol. 52, No. 4, pp.357-365.

Mingant, L., Tirtaine, C. and Augros, J. (2015) Film Marketing into the Twenty First Century, British Film Institute, UK.

Nikolaidou, A. and Poupou, A. (2017) 'Post-weird notes on the new wave of Greek cinema catalogue', 58th Thessaloniki International Film Festival, pp.88-105.

Nucci, M. (2018) 'Social media and participatory authorship in giant screen films', The Museum Journal, Vol. 61, No. 2, pp.285-300.

Paliszkiewicz, J. and Koohang, A. (2016) Social Media and Trust: A Multinational Study of University Students, Informing Science Press, US.

Parry, R. (2011) The Ascent of Media: From Gilgamesh to Google via Gutenberg, Nicholas Brealey Publishing, UK.

Proffitt, J.M., Tchoi, D.Y. and McAllister, M.P. (2007) 'Plugging back into The Matrix', Journal of Communication Inquiry, Vol. 31, No. 3, pp.239-254. 
Ra, H., Sejin, H. and Sun-Hwa K. (2018) 'Narrative persuasion in social media: an empirical study of luxury brand advertising', Journal of Research in Interactive Marketing, Vol. 12, No. 3, pp.274-292.

Rime, B. (2007) 'The social sharing of emotion as an interface between individual and collective processes in the construction of emotional climates', Journal of Social Issues, Vol. 63, No. 2, pp.307-322.

Schroeder, J.E. (2017) 'Corporate branding in perspective: a typology', European Journal of Marketing, Vol. 51, Nos. 9/10, pp.1522-1529.

Scolari, C.A. (2009) 'Transmedia Storytelling: implicit consumers, narrative worlds, and branding in contemporary media production', International Journal of Communication, Vol. 3, pp.586-606 [online] http://beta.upc.edu.pe/matematica/portafolios/nmynt/transmedia _storytelling-pdf (accessed 1 December 2019).

Sifaki, E. and Papadopoulou, M. (2015) 'Advertising modern art: a semiotic analysis of posters used to communicate about the Turner Prize award', Visual Communication, Vol. 14, No. 4, pp.457-484.

Sifaki, E., Stamou, N. and Papadopoulou, M. (2016) The Emergence and Creation of a 'Weird Wave' in the Greek Cinema: the Scientific and Media Discourse and the Role of Marketing, Unpublished Research Report, European Parliament.

Symeou, P., Bantimaroudis, P. and Zyglidopoulos, S. (2015) 'Cultural agenda setting and the role of critics: an empirical examination in the market for art-house films', Communication Research, Vol. 42, No. 5, pp.732-754.

Touwr, Q. (2011) Adopting the Art house Cinema Identity: A Viable Strategy?, Unblished Master Thesis, Business Studies, University of Amsterdam, Amsterdam.

Ulrike, M. (2002) Emotional Branding: Playing with the Senses: A Conceptual Approach, Unpublished Diploma thesis, German National Library [online] https://books.google.gr/books?id=FvpjAQAAQBAJ\&dq=marc+gobe+emotional+branding++ Max+2002\&lr=\&hl=el\&source=gbs_navlinks_s (accessed 12 July 2019).

Usher, N. (2010) 'Why Spreadable Doesn't Equal Viral: A Conversation With Henry Jenkins', Niema Lab. Retrieved from http://www.niemanlab.org/2010/11/why-spreadable-doesnt-equalviral-a-conversation-with-henry-jenkins/ (Accessed 12 July 2019).

van Laer, T., Feiereisen, S. and Visconti, L.M. (2019) 'Storytelling in the digital era: a metaanalysis of relevant moderators of the narrative transportation effect', Journal of Business Research, Vol. 96, pp.135-146.

Wilson, R.F. (2012) 'The Six Simple Principles of Viral Marketing', Practical Ecommerce [online] https://www.practicalecommerce.com/viral-principles (accessed 15 July 2019).

Yang, B. and Zisiadis, M. (2014) Transmedia Marketing: Strengthening Multiplatform User Participation through Storytelling, Independent Thesis Advanced Level, Umea University [online] http://umu.diva-portal.org/smash/get/diva2:727294/FULLTEXT03.pdf (accessed 15 July 2019).

Zaichkowsky, L.J., Chuu, L.H.S. and Chang, C.J. (2009) 'Exploring art film audiences: a marketing analysis', Journal of Promotion Management, Vol. 15, No. 1, pp.212-228.

Zeiser, A. (2015) Transmedia Marketing: From Film and TV to Games and Digital Media, Focal Press/Routledge [online] https://www.routledge.com/Transmedia-Marketing-From-Film-andTV-to-Games-and-Digital-Media/Zeiser/p/book/9780415716116 (accessed 1 December 2019). 